\title{
Nematode communities in three types of grassland in the Slovak Republic
}

\author{
A. ČEREVKOVÁ
}

Parasitological Institute of the Slovak Academy of Sciences, Hlinková 3, 04001 Košice, Slovak Republic; E-mail:cerev@saske.sk

\begin{abstract}
Summary
Nematode communities were studied and compared in three different types of grassland throughout the Slovak Republic: new meadow (established during last 3 years), permanent meadow and permanent pasture. A total of 85 nematode species from 64 genera were found. The identified nematode species belonged mainly to the orders Tylenchida (31), Dorylaimida (22), and Rhabditida (12). The most abundant species were Helicotylenchus digonicus, Rhabditis spp., Filenchus filiformis and Enchodelus macrodorus in new meadows, H. digonicus and E. macrodorus in permanent meadows and $H$. digonicus and Aporcelaimellus obtusicaudatus in permanent pastures. Plant parasitic nematodes were dominant in all investigated types of grassland, followed by bacterial feeders in new meadows and omnivores in permanent meadows and pastures. Maturity index (MI) and B/F depended with the age of grassland and thus with succession from newly established meadows to permanent meadows and permanent pastures. Nematode communities were more similar in permanent meadows and pastures than in new meadows and were also influenced by geographic condition.
\end{abstract}

Key words: nematode communities; grassland; Slovak Republic

\section{Introduction}

Nematodes as the most abundant Metazoa with various feeding habits and life history strategies have a great capability of adapting to fluctuations in environment (Yeates, 1996) and therefore the analysis of nematodes communities structure is being used more frequently as a tool in ecological studies (Bongers, 1990). Diversity and abundance of soil nematode communities decrease with intensity of land cultivation or human interference, after approximately a decade a soil fauna is able repeatedly recover within values similar to those in natural ecosystems (Háněl, 2003).
Grassland is a widespread type of ecosystem in the Slovak Republic where it takes over $33 \%$ of agricultural areas but studies on nematode communities in grassland ecosystem in the Slovak Republic are scarce. Some information on nematode communities on grassland in the Slovak Republic were published by Šály (1983), Valocká and Sabová (1997) compare two types of grassland, Valocká et al. (2001) investigated nematode communities in natural permanent grass ecosystems and regularly cultivated cereal agroecosystems and Lišková and Čerevková (2005) compared nematode communities of river banks and adjacent meadows.

Investigation focused on the changes of soil nematode communities on meadows differing in age are presented in studies Wasilewska (1994), Valocká and Sabová (1997) and Háněl (2003).

The aim of this paper was to survey the occurrence and distribution of soil and plant parasitic nematodes of grassland and to compare the structures of nematode communities in three types of grassland of different age and utilisation in various regions of the Slovak Republic.

\section{Material and Methods}

Communities of soil free living and plant parasitic nematodes were studied at four selected localities in the mountain and submontane areas where grassland is a widespread ecosystem type in the Slovak Republic. Soil samples were collected in each locality from all three types of grassland; new meadow - newly established on arable soil during last 3 years, fertilized and regularly mown with dominant species of Dactylis glomerata L., Festuca rubra L. and Lolium perene L. with the varied $\mathrm{pH}\left(\mathrm{H}_{2} \mathrm{O}\right) 7.00-8.21$, $\mathrm{C}_{\mathrm{ox}} 3.83$ - 5.22; permanent meadow, covered with indigenous multispecies vegetation irregularly mown, $\mathrm{pH}$ $\left(\mathrm{H}_{2} \mathrm{O}\right) 7.06-7.24, \mathrm{C}_{\mathrm{ox}} 3.42-6.16$; and permanent pasture with indigenous vegetation regularly grazed, $\mathrm{pH}\left(\mathrm{H}_{2} \mathrm{O}\right)$ 
$6.95-7.36, \mathrm{C}_{\mathrm{ox}} 4.35-4.97$.

Characteristic of localities:

Vel'ký Folkmár: orographic unit Čierna hora, at altitude $640 \mathrm{~m}$ a.s.l., $48^{\circ} 51^{\prime} \mathrm{N}, 21^{\circ} 10^{\prime} \mathrm{E}$, clay, loamy soil, sampling date: October 2003.

Telgárt: orographic unit Horehronské podolie, at altitude $1006 \mathrm{~m}$ a.s.l., $48^{\circ} 51^{\prime} \mathrm{N}, 20^{\circ} 11^{\prime} \mathrm{E}$, loamy soil, sampling date: October 2003.

Lubietová, Strelníky: orographic unit Zvolenská kotlina, Lubietová at altitude $559 \mathrm{~m}$ a.s.l., $48^{\circ} 45^{\prime} \mathrm{N}, 19^{\circ} 22^{\prime} \mathrm{E}$, Strelníky at altitude $739 \mathrm{~m}$ a.s.l., $48^{\circ} 43^{\prime} \mathrm{N}, 19^{\circ} 23^{\prime} \mathrm{E}$, loamy, gravelled soil, sampling date: October 2004

Vrbovce: orographic unit Biele Karpaty, at altitude $360 \mathrm{~m}$ a.s.l., $48^{\circ} 47^{\prime} \mathrm{N}, 17^{\circ} 28^{\prime} \mathrm{E}$, loamy, gravelled soil, sampling date: October 2004.

Nematodes were isolated from $500 \mathrm{~g}$ of the mixed soil using the Coob's flotation-sieving method, fixed in FAA and studied in permanent glycerine slides. Juveniles (juvs.) were identified to genera. Nematode species and genera were allocated to the trophic groups according to Yeates et al. (1993) and Bongers (1990). For evaluation of diversity and ecology of nematode communities the following parameters were used: abundance of nematodes in $500 \mathrm{~g}$ of soil, Shannon-Weaver Index (H'spp) calculated for species (Shannon \& Weaver, 1949), Maturity Index (MI) and Plant Parasitic Index (PPI) proposed by Bongers (1990), PPI/MI ratio introduced by Bongers and Korthals (1995) and B/F ratio proposed by Wasilewska (1997). All indices, as well as a number of species, total abundance of nematodes, and percentage proportion of trophic groups are calculated as the mean value with standard deviation for all types of grassland. Statistical calculations were performed using the STATISTICA (StatSoft, 2001).

\section{Results}

A total of 85 species from 64 genera, included unidentified larvae listed as nematode sp. were found (Table 1); 62 species and 47 genera in new meadows; 62 and 49 in permanent meadows; 62 and 49 in permanent pastures among those 38 species from 33 genera were common in all three types of investigated grassland. The majority of identified nematodes species belonged to the orders Tylenchida (31), Dorylaimida (22), Rhabditida (12). The abundance of nematodes was higher on permanent pastures (mean value of 569) than under permanent meadows (mean value of 440) and new meadows (mean value of 410 ).

Plant parasitic nematodes were dominant trophic group in all investigated meadows (Table 2). In general, species $\mathrm{He}$ licotylenchus digonicus, Pratylenchus pratensis, Bitylenchus dubius and the genus Criconemoides prevailed in new meadows. In permanent pastures plant feeders were represented by the species $H$. digonicus, $H$. canadensis, $H$. pseudorobustus, Mesocriconema curvatum, Rotylenchus goodeyi and P. pratensis, in permanent meadows the genus Helicotylenchus was dominant.

Bacterial feeders were subdominant trophic group only in new meadows (over $21 \%$ ) and the most abundant genera were Rhabditis and Chiloplacus. On the other hand, omnivores, characterized by a long life cycle, were subdominant trophic group in permanent meadows $(28 \%)$ and pastures (24\%) represented by the species Enchodelus macrodorus, Aporcelaimellus obtusicaudatus, Mesodorylaimus bastiani, and Oxydirus oxycephalus. The following trophic groups

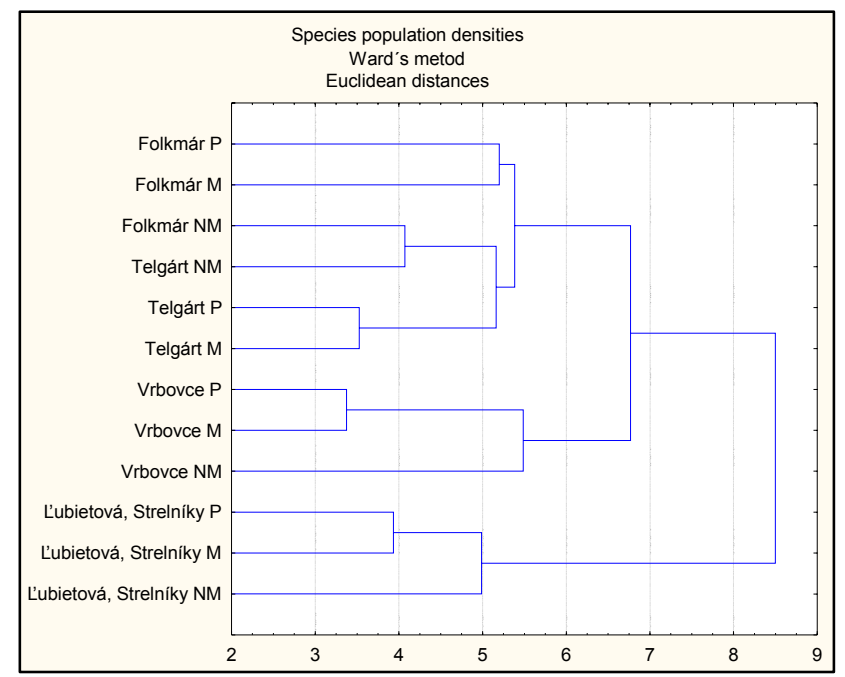

Fig. 1 Dendrogram of cluster analysis of nematode species in individual sites, data $\log (\mathrm{x}+1)$, where $\mathrm{x}=$ species population density. New meadow - NM, permanent meadow - M, permanet pasture $-\mathrm{P}$

was the group of fungal feeders. At one particular locality (Lubietová) - new meadows - higher abundance of Diphtherophora communis was found. The proportions of predators were variable in investigated types of grassland. Species Tripyla filicaudata had the highest abundance in new meadows and Anatonchus tridentatus and Coomanchus parvus in permanent meadows and pastures.

The species diversity (H'spp) ranged between $2.2-2.5$, no demonstrable differences were observed among investigated sites.

The Maturity index (MI) values were lover in new meadows (2.9) than in permanent meadows (3.4) or in permanent pastures (3.5) (Mann-Whitney $U$ test, $\mathrm{z}=-1.84, \mathrm{p}<$ 0.05 ) and depends with a higher number of omnivores and predators with higher c-p values. The PPI (Plant parasite index) values were similar in all investigated types of grassland, no apparent differences were observed. The higher proportion of bacterial feeders was reflected in the $\mathrm{B} / \mathrm{F}$ ratio, which was very high in new meadows (6.3) (Mann-Whitney $U$ test; $\mathrm{z}=2.2 \mathrm{p}<0.05$ ) compared to permanent meadows (3.2) and to permanent pastures (2.1). Cluster analysis showed the similarity of the structure of nematode communities in all sites (Fig. 1), but locality L'ubietová, Strelníky standed out from the sample groups, as it was influenced by abundance and diversity of omnivores like E. macrodorus, Dorylaimoides micoletzkyi, Eudorylaimus spp. and fungivores D. communis. Diversity and abundance of soil nematodes is more similar in permanent meadows and pastures than in new meadows. 
Table 1. Structure of nematode communities of three types of grassland in the Slovak Republic: mean abundance (individuals per $500 \mathrm{~g}$ soil; mean \pm $\mathrm{SD} ; n=4) \mathrm{TG}$ - trophic groups, $\mathrm{B}$ - bacteriovores, $\mathrm{F}$ - fungivores, $\mathrm{PP}$ - plant parasites, RFF - root-fungal feeders, $\mathrm{O}$ - omnivores, $\mathrm{P}$ - predators, IN - insect parasites

\begin{tabular}{|c|c|c|c|c|}
\hline Nematodes & TG & New meadows & Permanet meadows & Permanent pastures \\
\hline \multicolumn{5}{|l|}{ Order: ARAEOLAIMIDA } \\
\hline 1 Anaplectus granulosus (Bastian, 1865) & $\mathrm{B}$ & $3.0 \pm 4.2$ & - & - \\
\hline Plectus parietinus Bastian, 1865 & $\mathrm{~B}$ & $0.5 \pm 0.5$ & - & $2.2 \pm 2.8$ \\
\hline Tylocephalus auriculatus (Bütschli, 1873) & $\mathrm{B}$ & - & $0.7 \pm 1.5$ & $0.2 \pm 0.5$ \\
\hline \multicolumn{5}{|l|}{ Order: RHABDITIDA } \\
\hline 4 Teratocephalus terrestris (Bütschli, 1873) & B & - & - & $1.2 \pm 2.5$ \\
\hline Cephalobus persegnis Bastian, 1865 & $\mathrm{~B}$ & $8.0 \pm 4.2$ & $6.5 \pm 6.4$ & $9.0 \pm 6.1$ \\
\hline $\begin{array}{l}6 \quad \text { Eucephalobus mucronatus (Kozlowska } \\
\text { \& Roguska-Wasilevska, 1963) }\end{array}$ & $\mathrm{B}$ & - & $2.0 \pm 4.0$ & $3.7 \pm 5.1$ \\
\hline Eucephalobus oxyuroides (de Man, 1876) & $\mathrm{B}$ & - & $1.2 \pm 1.8$ & $0.5 \pm 1.0$ \\
\hline Eucephalobus striatus (Bastian, 1865) & $\mathrm{B}$ & $5.7 \pm 7.5$ & $1.2 \pm 1.8$ & $0.7 \pm 1.5$ \\
\hline Acrobeloides nanus (de Man, 1880) & $\mathrm{B}$ & $5.2 . \pm 6.7$ & $6.2 \pm 5.8$ & $17.5 \pm 1.7$ \\
\hline 10 Chiloplacus propinquus (de Man, 1921) & B & $2.0 \pm 2.7$ & $0.2 \pm 0.5$ & $1.7 \pm 3.5$ \\
\hline 11 Chiloplacus symmetricus (Thorne, 1925) & $\mathrm{B}$ & $12.5 \pm 14.7$ & $5.2 \pm 6.7$ & $0.7 \pm 1.5$ \\
\hline 12 Panagrolaimus rigidus (Schneider, 1866) & $\mathrm{B}$ & $4.2 \pm 5.3$ & $0.7 \pm 1.5$ & $0.2 \pm 0.5$ \\
\hline 13 Protorhabditis postneri (Körner, 1952) & $\mathrm{B}$ & $0.2 \pm 0.5$ & - & - \\
\hline 14 Rhabditis spp. juvs. & $\mathrm{B}$ & $29.2 \pm 49.9$ & $13.0 \pm 75.0$ & $2.7 \pm 4.8$ \\
\hline 15 Heterorhabditis sp. juvs. & IN & - & $0.2 \pm 0.5$ & $1.2 \pm 2.5$ \\
\hline 16 Steinernema affine (Bovien, 1937) & IN & $0.2 \pm 0.5$ & $1.5+2.3$ & $0.7 \pm 0.5$ \\
\hline \multicolumn{5}{|l|}{ Order: APHELENCHIDA } \\
\hline 17 Aphelenchus avenae Bastian, 1865 & $\mathrm{~F}$ & $9.7 \pm 0.5$ & $12.2 \pm 14.1$ & $8.2 \pm 4.7$ \\
\hline 18 Aphelenchoides composticola Franklin, 1957 & $\mathrm{~F}$ & $1.2 \pm 1.8$ & - & - \\
\hline 19 Aphelenchoides parietinus (Bastian, 1865) & $\mathrm{F}$ & - & $0.2 \pm 0.5$ & $0.5 \pm 1.0$ \\
\hline 20 Aphelenchoides sp. juvs. & $\mathrm{F}$ & $0.5 \pm 0.5$ & - & $0.2 \pm 0.5$ \\
\hline $\begin{array}{l}21 \text { Paraphelenchus pseudoparietinus Micoletzky, } 1922 \\
\text { Order: TYLENCHIDA }\end{array}$ & $\mathrm{F}$ & - & $3.0 \pm 6.0$ & - \\
\hline 22 Basiria gracilis (Thorne, 1949) & RFF & $15.0 \pm 30.0$ & $3.7 \pm 5.1$ & $3.2 \pm 6.5$ \\
\hline 23 Boleodorus acutus Thorne et Malek, 1968 & RFF & $0.5 \pm 1.0$ & $3.2 \pm 6.5$ & $0.2 \pm 0.5$ \\
\hline 24 Boleodorus thylactus Thorne, 1941 & RFF & $0.5 \pm 0.5$ & - & $1.0 \pm 1.4$ \\
\hline 25 Neopsilenchus magnidens (Thorne, 1949) & RFF & - & $4.5 \pm 4.6$ & - \\
\hline 26 Filenchus filiformis (Bütschli, 1873) & RFF & $21.2 \pm 28.3$ & $7.2 \pm 6.3$ & $9.2 \pm 10.9$ \\
\hline 27 Tylenchus davainei Bastian, 1865 & RFF & $1.0 \pm 2.0$ & $0.7 \pm 1.5$ & - \\
\hline 28 Tylenchus sp. juvs & RFF & $1.5 \pm 2.3$ & $1.2 \pm 1.8$ & $12.5 \pm 17.4$ \\
\hline 29 Malenchus bryophilus (Steiner, 1914) & RFF & $3.0 \pm 2.9$ & $0.2+0.5$ & $1.0 \pm 2.0$ \\
\hline 30 Malenchus exiguus (Massey, 1969) & RFF & - & $0.5 \pm 0.5$ & $0.7 \pm 1.5$ \\
\hline 31 Aglenchus agricola (de Man, 1884) & RFF & $6.0 \pm 10.7$ & $6.0 \pm 6.9$ & $7.2 \pm 11.4$ \\
\hline 32 Coslenchus costatus (de Man, 1921) & RFF & $5.7 \pm 10.8$ & $1.5 \pm 1.7$ & $2.7 \pm 3.7$ \\
\hline 33 Ditylenchus intermedius (de Man, 1880) & $\mathrm{F}$ & $0.2 \pm 0.5$ & $0.5 \pm 1.0$ & - \\
\hline 34 Nothotylenchus acris Thorne, 1941 & $\mathrm{~F}$ & $0.2 \pm 0.5$ & $1.0 \pm 2.0$ & $0.2 \pm 0.5$ \\
\hline 35 Bitylenchus dubius (Bütschli, 1873) & PP & $13.5 \pm 25.6$ & - & - \\
\hline 36 Tylenchorhynchus sp. juvs. & PP & - & $0.2 \pm 0.5$ & $3.0 \pm 5.3$ \\
\hline 37 Heterodera avenae Wollenweber, 1924 & PP & $0.5 \pm 1.5$ & - & $0.2 \pm 0.5$ \\
\hline 38 Rotylenchus goodeyi Loof \& Oostenbrink, 1958 & PP & $4.0 \pm 8.0$ & $3.0 \pm 2.9$ & $7.2 \pm 8.3$ \\
\hline 39 Rotylenchus pumilus (Perry, 1959) & PP & $0.7 \pm 1.5$ & $1.0 \pm 2.0$ & $0.7 \pm 0.9$ \\
\hline 40 Rotylenchus robustus (de Man, 1876) & PP & - & $1.5 \pm 3.0$ & $1.2 \pm 2.5$ \\
\hline 41 Helicotylenchus canadensis Waseem, 1961 & PP & $12.0 \pm 23.3$ & $14.2 \pm 19.8$ & $24.0 \pm 27.1$ \\
\hline 42 Helicotylenchus digonicus Perry, 1959 & PP & $95.0 \pm 33.8$ & $208.5 \pm 348.1$ & $329.0 \pm 394.7$ \\
\hline 43 Helicotylenchus pseudorobustus (Steiner, 1914) & PP & $1.0 \pm 2.0$ & $6.5 \pm 11.7$ & $7.7 \pm 11.6$ \\
\hline 44 Pratylenchoides crenicauda Winslow, 1958 & PP & - & $1.5 \pm 3.0$ & - \\
\hline 45 Pratylenchus neglectus (Rensch, 1924) & PP & $1.5 \pm 1.7$ & - & - \\
\hline 46 Pratylenchus pratensis (de Man, 1880) & PP & $17.5 \pm 16.5$ & $1.5 \pm 1.7$ & $8.6 \pm 5.5$ \\
\hline 47 Paratylenchus bukowinensis Micoletzky, 1922 & PP & $1.2 \pm 2.5$ & $2.2 \pm 4.5$ & $1.0 \pm 1.1$ \\
\hline 48 Paratylenchus elachistus Steiner, 1949 & PP & $0.2 \pm 0.5$ & $1.7 \pm 2.3$ & - \\
\hline
\end{tabular}




\begin{tabular}{|c|c|c|c|c|}
\hline 49 Paratylenchus hamatus Thorne \& Allen, 1950 & PP & $0.2 \pm 0.5$ & $1.0 \pm 2.0$ & - \\
\hline 50 Criconemoides informis (Micoletzky, 1922) & PP & $4.0 \pm 8.0$ & $0.2 \pm 0.5$ & $0.2 \pm 0.5$ \\
\hline 51 Criconemoides sp. juvs. & PP & $3.2 \pm 3.9$ & - & - \\
\hline 52 Mesocriconema curvatum (Raski, 1952) & PP & - & - & $7.0 \pm 14.0$ \\
\hline \multicolumn{5}{|l|}{ Order: ENOPLIDA } \\
\hline 53 Tripyla filicaudata de Man, 1880 & $\mathrm{P}$ & $2.7 \pm 2.7$ & $1.5 \pm 2.3$ & $2.5 \pm 3.3$ \\
\hline 54 Prismatolaimus intermedius (Bütschli, 1873) & $\mathrm{P}$ & - & $1.0 \pm 2.0$ & - \\
\hline \multicolumn{5}{|l|}{ Order: ALAIMIDA } \\
\hline 55 Alaimus primitivus de Man, 1880 & B & $10.7 \pm 13.5$ & $11.2 \pm 8.1$ & $6.2 \pm 10.0$ \\
\hline 56 Paramphidelus dolichurus (de Man, 1876) & B & $1.2 \pm 1.5$ & $2.0 \pm 2.8$ & $4.5 \pm 7.6$ \\
\hline \multicolumn{5}{|l|}{ Order: MONONCHIDA } \\
\hline 57 Clarkus papillatus (Bastian, 1865) & $\mathrm{P}$ & $0.5 \pm 1.0$ & - & $0.2 \pm 0.5$ \\
\hline 58 Coomansus parvus (de Man, 1880) & $\mathrm{P}$ & $1.5 \pm 1.9$ & $1.7 \pm 1.2$ & $2.5 \pm 1.9$ \\
\hline 59 Prionchulus muscorum (Dujardin, 1845) & $\mathrm{P}$ & $2.0 \pm 2.8$ & - & - \\
\hline 60 Mylonchulus brachyuris (Bütschli, 1873) & $\mathrm{P}$ & $0.5 \pm 1.0$ & - & - \\
\hline 61 Mylonchulus sigmaturus (Cobb, 1917) & $\mathrm{P}$ & $3.0 \pm 6.0$ & - & $0.2 \pm 0.5$ \\
\hline 62 Anatonchus tridentatus (de Man, 1876) & $\mathrm{P}$ & $1.2 \pm 0.9$ & $3.0 \pm 4.2$ & $2.0 \pm 1.6$ \\
\hline 63 Miconchus studeri (Steiner, 1914) & $\mathrm{P}$ & $0.2 \pm 0.5$ & - & - \\
\hline \multicolumn{5}{|l|}{ Order: DORYLAIMIDA } \\
\hline 64 Prodorylaimus brigdammensis de Man, 1876 & $\mathrm{O}$ & $3.0 \pm 6.0$ & $2.0 \pm 4.0$ & - \\
\hline 65 Mesodorylaimus bastiani (Bütschli, 1873) & $\mathrm{O}$ & $3.2 \pm 2.9$ & $5.7 \pm 0.5$ & $17.0 \pm 15.6$ \\
\hline 66 Mesodorylaimus bastianoides Meyl, 1961 & $\mathrm{O}$ & $1.5 \pm 3.0$ & - & - \\
\hline 67 Mesodorylaimus centrocercus (de Man, 1880) & $\mathrm{O}$ & $0.2 \pm 0.5$ & $0.2 \pm 0.5$ & $0.5 \pm 1.0$ \\
\hline 68 Aporcelaimellus obtusicaudatus (Bastian 1865) & $\mathrm{O}$ & $7.2 \pm 10.8$ & $14.2 \pm 12.5$ & $22.0 \pm 31.2$ \\
\hline 69 Paraxonchium laetificans (Andrássy, 1956) & $\mathrm{O}$ & - & - & $0.2 \pm 0.5$ \\
\hline 70 Discolaimus texanus Cobb, 1913 & $\mathrm{O}$ & - & $0.7 \pm 1.5$ & $0.2 \pm 0.5$ \\
\hline 71 Epidorylaimus lugdunensis (de Man, 1880) & $\mathrm{O}$ & $0.5 \pm 1.0$ & $1.0 \pm 2.0$ & - \\
\hline 72 Eudorylaimus carteri (Bastian, 1865) & $\mathrm{O}$ & $8.0 \pm 16.0$ & $0.7 \pm 1.5$ & $1.0 \pm 2.0$ \\
\hline 73 Eudorylaimus iners (Bastian, 1865) & $\mathrm{O}$ & $1.0 \pm 2.0$ & - & $0.2 \pm 0.5$ \\
\hline 74 Eudorylaimus spp. juvs. & $\mathrm{O}$ & $13.0 \pm 26.0$ & $5.0 \pm 10.0$ & $1.7 \pm 3.5$ \\
\hline 75 Microdorylaimus parvus (de Man, 1880) & $\mathrm{O}$ & - & $1.7 \pm 3.5$ & - \\
\hline 76 Thonus ettersbergensis (de Man, 1885) & $\mathrm{O}$ & - & $5.5 \pm 11.0$ & - \\
\hline 77 Enchodelus macrodorus (de Man, 1880) & $\mathrm{O}$ & $20.0 \pm 30.8$ & $20.7 \pm 19.7$ & $10.0 \pm 8.6$ \\
\hline 78 Pungentus silvestris (de Man, 1912) & $\mathrm{O}$ & - & $4.0 \pm 8.0$ & $9.5 \pm 12.7$ \\
\hline 79 Longidorus elongatus (de Man, 1876) & PP & - & $3.0 \pm 6.0$ & - \\
\hline 80 Longidorus leptocephalus Hooper, 1961 & PP & - & $6.5 \pm 13.0$ & $1.2 \pm 1.5$ \\
\hline 81 Axonchium coronatum (de Man, 1906) & $\mathrm{O}$ & $0.2 \pm 0.5$ & $1.2 \pm 2.5$ & $4.7 \pm 9.5$ \\
\hline 82 Oxydirus oxycephalus (de Man, 1885) & $\mathrm{O}$ & $5.0 \pm 6.0$ & $11.5 \pm 9.8$ & $9.6 \pm 13.3$ \\
\hline 83 Dorylaimellus mirabilis (de Man, 1876) & $\mathrm{O}$ & - & - & $4.2 \pm 8.5$ \\
\hline 84 Dorrylium zeelandicum (de Man, 1876) & $\mathrm{F}$ & - & - & $0.5 \pm 1.0$ \\
\hline 85 Tylencholaimus sp. juvs. & $\mathrm{F}$ & $2.5 \pm 3.3$ & $0.5 \pm 1.0$ & $2.0 \pm 2.8$ \\
\hline 86 Dorylaimoides micoletzkyi (de Man, 1921) & $\mathrm{O}$ & $11.0 \pm 22.0$ & $0.75 \pm 1.5$ & $0.5 \pm 1.0$ \\
\hline \multicolumn{5}{|l|}{ Order: TRIPLONCHIDA } \\
\hline 87 Diphtherophora communis de Man, 1880 & $\mathrm{~F}$ & $18.7 \pm 35.5$ & - & $2.0 \pm 2.6$ \\
\hline
\end{tabular}

\section{Discussion}

Investigated nematode communities inhabiting grassland habitats in the Slovak Republic were analyzed and compared in three different types of meadows differing in age and utilization. Obtained results indicated that numbers of species and genera were little differentiated in all investigated types of grassland. The number of genera (47) in new meadows established in arable soil was higher than presented by Valocká and Sabová (1997) (38) in young two-years ley meadow but the same as obtained by Háněl (2003) (46) in abandoned field left to natural succession.
The number of genera in permanent meadows (49) and permanent pastures (49) is comparable with the results of Valocká and Sabová (1997) (43) genera in permanent pastures and Wasilewska (1995) (48) genera in permanent meadows.

Plant parasites nematodes were dominant in all three types of grassland studied. This is in concordance with the results of Yeates and Bird (1994), Valocká et al. (2001) and Lišková and Čerevková (2005). Plant feeders were represented mostly by the genus Helicotylenchus which is often 
Table 2. Nematode community structure in different types of grassland in the Slovak Republic (mean $\pm \mathrm{SD} ; n=4)$

\begin{tabular}{lccc}
\hline Indices & New meadows & Permanent meadows & Permanent pastures \\
\hline Total abundance (500g soil) & $410.0 \pm 163.6$ & $440.2 \pm 451.4$ & $569.0 \pm 508.7$ \\
Number of species & $29.0 \pm 5.1$ & $29.0 \pm 8.1$ & $30.0 \pm 3.6$ \\
Bacterial feeders \% & $21.8 \pm 11.5$ & $14.2 \pm 7.2$ & $7.9 \pm 5.0$ \\
Fungal feeders \% & $4.3 \pm 2.9$ & $4.2 \pm 0.6$ & $3.6 \pm 1.5$ \\
Plant parasites feeders \% & $45.8 \pm 14.9$ & $41.2 \pm 27.1$ & $56.1 \pm 30.2$ \\
Root-fungal feeders \% & $7.0 \pm 7.8$ & $8.6 \pm 4.9$ & $4.9 \pm 4.2$ \\
Omnivores \% & $17.8 \pm 16.1$ & $28.4 \pm 18.9$ & $24.2 \pm 23.4$ \\
Predators \% & $2.9 \pm 2.1$ & $2.3 \pm 2.4$ & $2.2 \pm 2.0$ \\
Insect parasites \% & $0.1 \pm 0.1$ & $0.7 \pm 0.8$ & $0.7 \pm 1.4$ \\
H'spp & $2.5 \pm 0.2$ & $2.5 \pm 0.5$ & $2.2 \pm 0.6$ \\
MI & $2.5 \pm 0.6$ & $3.4 \pm 0.5$ & $3.5 \pm 0.6$ \\
PPI & $2.5 \pm 0.2$ & $2.6 \pm 0.3$ & $2.7 \pm 0.1$ \\
PPI/MI & $0.9 \pm 0.3$ & $0.7 \pm 0.2$ & $0.8 \pm 0.2$ \\
B/F & $6.3 \pm 2.9$ & $3.2 \pm 1.3$ & $2.1 \pm 1.0$ \\
\hline
\end{tabular}

associated with permanent grassland. In new meadows higher abundance of $B$. dubius was observed often occurring in cultivated fields in the Slovak Republic (Sabová et al., 1986; Renčo, 2002) was found. In contrary to our results Háněl (1996) observed the bacterial feeders and omnivores as the most abundant trophic groups of nematodes in the South Bohemia meadows.

Bacterial feeders represented mainly by Rhabditis and Chiloplacus were subdominant trophic group only in new meadows. Higher abundance of bacterial feeders in new meadows was probably caused by higher supplies of nitrogen from previous mineral fertilisation in arable soil. Wasilewska (1997) reported increase abundance of bacterial feeders is closely connected with an expansion of microbial activity, in particular in situations with supplies of nitrogen in the environment.

On the other hand, omnivores characterized by a long life cycle and low abundance especially in cultivated field (Yeates \& Bird, 1994), were subdominant in permanent meadows and pastures. They were represented mostly by E. macrodorus, A. obtusicaudatus and O. oxycephalus. Predators represented only a low proportion of the nematode communities in all investigated sites, but together with omnivores as indicators of stability and naturalness of ecosystems (Wasilewska, 1997), their high proportions in the nematode community on permanent meadows and pastures are indicative of a higher stability at this ecosystems.

The nematode diversity (H'spp) were similar in all types of meadows and lover then those found by Wasilewska (1994) or Háněl (1996) but comparable to the data obtained by Háněl (1994) and Lišková and Čerevková (2005).

The comparison of three types of the grassland in the Slovak Republic showed that the MI values are higher in permanent meadows and pastures than in new meadows. A depend of the MI with the age of meadows was obtained by Wasilewska (1995) and Valocká and Sabová (1997), and with succession from new meadows to permanent meadows and pastures. The values of the PPI (Plant parasite index) were rather balanced in all investigated types of grassland. The $\mathrm{B} / \mathrm{F}$ ratio reflected a higher proportion of bacterial feeders which increased in higher decomposition of organic matter; therefore these values are higher in new meadows than in permanent meadows and pastures.

Cluster analysis showed that the structure of nematode communities and diversity more dependent on geographic conditions than on meadows age and utilization.

\section{Acknowledgements}

This study was partially supported by scientific grant agency VEGA, grant no. 2/4176/04 and by the Science and Technology Assistance Agency, project no. 51-014604.

\section{References}

BONGERS, T. (1990): The maturity index: an ecological measure of environmental disturbance based on nematode species composition. Oecologia, 83: $14-19$

BONGERS, T., KORTHALS, G. (1995): The behaviour of MI and PPI under enriched conditions. Nematologica, 41: 286 HÁNĚL, L. (1994): Soil nematodes (Nematode) of some localities in the Krkonoše Mts. Opera corcont., 31: 105 113

HÁNĚL, L. (1996): Composition and seasonal changes of soil nematode community in a South Bohemian meadow. Acta Soc. Zool. Bohem., 60: 103 - 114

HÁNĚL, L. (2003): Recovery of soil nematode populations from cropping stress by natural secondary succession to meadow land. Appl. Soil Ecol., 22: 255 - 270

LiŠKOVÁ, M., ČEREVKOVÁ, A. (2005): Nematode communities of river banks and adjacent meadows in the Slovak Republic. Helminthologia, 42: 223 - 232

RENČO, M. (2002): Seasonal dynamics of plant parasitic and free living nematodes in sugar beet, cereals and lucerne field in East Slovakia. Helminthologia, 39: 51 - 57 SABOVÁ, M., VALOCKÁ, B., LIŠKOVÁ, M. (1986): Parasitic nematodes in monoculture cereals and sowing plan. Biologia, 41: 135 - 141 
ŠÁLY, A. (1983): Free living nematodes in the SSR. VEDA, Published House SAV, Bratislava

ShannON, C. E., WeAVER, W. (1949): The Mathematical Theory of Communication. Urbana, University of Illinois Press

STATSOFT, INC. (2001): STATISTICA Cz [Softwarový systém na analýzu dat], verze 6 . [Software system for data analysis], Release 6], Www.StatSoft.Cz, (in Czech and English)

VAlockÁ, B., SABovÁ, M. (1997): Communities of soil and plant nematodes in two types of grass land. Helminthologia, 34: 97 - 103

VAlockÁ, B., SABovÁ, M., RenČO, M. (2001): Soil and plant nematode communities of two types of ecosystems. Helminthologia, 38: 105 - 109

WASILEWSKA, L. (1994): The effect of age of meadows on succession and diversity in soil nematode communities.

RECEIVED FEBRUARY 10, 2006
Pedobiologia, 28: 1 - 11

WASILEWSKA, L. (1995): Differences in development of soil nematode communities in single- and multi- species grass experimental treatments. Appl. Soil Ecol., 2: $53-64$ WASILEWSKA, L. (1997): Soil invertebrates as bioindicators, with special reference to soil-inhabiting nematodes. Russ. J. Nematol., 5: $113-126$

Yeates, G. W., Bongers, T., De Goede, R. G. M., Freckman, D. W., Georgieva, S. S. (1993): Feeding habits in soil nematode families and genera - An outline for soil ecologists. J. Nematol., 25: 315 - 331

YeAtes, G. W. (1996): Nematode ecology. Russ. J. Nematol., $4: 71-75$

YeAtes, G. W., BIRD, A. F. (1994): Some observations on the influence of agricultural practises on the nematode faunae of some South Australian soils. Fund. Appl. Nematol., 17: $133-145$

ACCEPTED JUNE 19, 2006 